\title{
A retrospective analysis of ectopic pregnancy at a tertiary care centre: one year study
}

\author{
Vandana Bhuria*, Smiti Nanda, Meenakshi Chauhan, Vani Malhotra
}

Department of Obstetrics and Gynaecology, Pt. B.D.S PGIMS, Rohtak, Haryana, India

Received: 30 April 2016

Accepted: 02 June 2016

\section{*Correspondence:}

Dr. Vandana Bhuria,

E-mail: drvandana882@gmail.com

Copyright: ( ) the author(s), publisher and licensee Medip Academy. This is an open-access article distributed under the terms of the Creative Commons Attribution Non-Commercial License, which permits unrestricted non-commercial use, distribution, and reproduction in any medium, provided the original work is properly cited.

\section{ABSTRACT}

Background: Ectopic pregnancy is an important cause of maternal morbidity and mortality especially in developing countries where the majority of patients present late with rupture and hemodynamic compromise. The aim of this study was to determine the risk factors, clinical profile of the patients and management options for ruptured ectopic pregnancies.

Methods: We conducted a retrospective study about ectopic pregnancy at obstetrics and gynaecology department over a period of one year, from 01 January 2015 to 31 December 2015. Information on the biosocial data, clinical symptoms and signs, risk factors for the disease, site of ectopic pregnancy and treatment options, quantity of hemoperitoneum and need for blood transfusion was extracted. The data was analyzed and presented in frequency tables and charts.

Results: Frequency of ectopic pregnancy was $1.6 \%$ of total 10235 deliveries. $131(89.1 \%)$ cases were of ruptured ectopic pregnancy. 147 patients underwent laparotomy while 22 patients were managed conservatively. All patients were symptomatic at presentation. Majority $(86,50.8 \%)$ of the patients were in the age group of 20-24 years. 33 $(19.5 \%)$ patients were nulliparous. Risk factors were found in $86(50.8 \%)$ patients. Majority $(38,44.1 \%)$ had history of previous tubal surgery (tubal sterilization and/or recanalisation) as risk factor. The highest number of ruptured ectopic occurred between 7-12 weeks of gestation. Most common surgical procedure employed was salpingectomy in $140(95.2 \%)$ patients. There was no maternal mortality due to ectopic pregnancy.

Conclusions: Ectopic pregnancy is still a major life threatening emergency condition which if treated early has good prognosis. Most cases present late making tubal conservation inapplicable. Efforts should be made towards woman education, improved hospital accessibility and better diagnostic skills.

Keywords: Ectopic pregnancy, Tubal sterilization, Recanalisation

\section{INTRODUCTION}

Ectopic pregnancy is a potentially life threatening condition which needs immense gynaecological importance, particularly in the developing world, because of high mortality and morbidity associated with it. It is the leading cause of maternal mortality in the first trimester and accounts for $10-15 \%$ of all maternal deaths. ${ }^{1}$ Ectopic pregnancy is an important cause of maternal morbidity and mortality especially in developing countries where the majority of patients present late with rupture and hemodynamic compromise. ${ }^{2}$ Apart from foetal wastage, maternal mortality and morbidity, ectopic pregnancy is also associated with repeat ectopic gestation and impairment of subsequent fertility. $^{3}$

Ectopic pregnancy is a global problem and has shown a rising incidence during last three decades the world over. This increase is associated with increase in pelvic infections, advances in assisted reproductive technology, tubal surgeries and sterilizations, use of intra-uterine 
devices, history of previous abortions, previous ectopic pregnancy, infertility, race and age above 35 years. ${ }^{4,5}$ However, ectopic pregnancy can occur without any obvious risk factor. ${ }^{5}$

The importance of ectopic pregnancy in our environment is peculiar, because rather than join the global trend of early diagnosis and conservative approach in management, we are challenged by late presentations with rupture in more than $80 \%$ of the cases. ${ }^{5}$ High index of suspicion is required for early diagnosis and management of ectopic pregnancy. Women of reproductive age presenting with history of amenorrhoea, abdominal pain, vaginal bleeding, syncopal attack and a positive pregnancy test, should undergo a diagnostic work-up to detect ectopic pregnancy. The treatment of ectopic pregnancy is influenced by clinical state of patient, the site of ectopic gestation, the reproductive wish of patient and the available facilities and technology.

Since ectopic pregnancy is a life threatening condition and a major health problem in the women of reproductive age group, the aim of this study was to determine the risk factors, clinical profile of the patients and management options for ruptured ectopic pregnancies.

\section{METHODS}

This was a retrospective study of ectopic pregnancies at a tertiary care centre from $1^{\text {st }}$ January 2015 to $31^{\text {st }}$ December 2015. The case notes of patients with ectopic pregnancy were traced through the accident and emergency department, gynaecology ward and operation theatre registers. The labour ward register was used to ascertain the total number of deliveries for the same period. Information on the biosocial data, clinical symptoms and signs, risk factors for the disease, site of ectopic pregnancy and treatment options, quantity of hemoperitoneum and need for blood transfusion was extracted. The data was analyzed with simple descriptive statistics and presented in frequency tables and charts.

\section{RESULTS}

In the review period, there were a total of 10235 deliveries and 169 cases of ectopic pregnancies giving an incidence of $1.6 \%$ of total deliveries. 131 (89.1\%) cases were of ruptured ectopic pregnancy, 9 cases with unruptured ectopic pregnancy and 7 patients had tubal abortion. 147 patients underwent laparotomy while 22 patients were managed conservatively.

Table 1 depicts the bio-demographic characteristics. Majority $(86,50.8 \%)$ of the patients were in the age group of 20-24 years followed by $63(30.8 \%)$ in the age group of 25-29 years (Table 1). 33 (19.5\%) patients were nulliparous while $72(42.6 \%)$ were pauciparous (Table 1$)$.
Table 1: Biodemographic chracteristics.

\begin{tabular}{|lll|}
\hline Age (years) & Number $(\mathbf{n = 1 6 9 )}$ & Percentage $(\%)$ \\
\hline$<20$ & 1 & 0.59 \\
\hline $20-24$ & 86 & 50.89 \\
\hline $25-29$ & 63 & 37.28 \\
\hline $30-34$ & 15 & 8.8 \\
\hline $35-39$ & 3 & 1.78 \\
\hline$>40$ & 1 & 0.59 \\
\hline Parity & & \\
\hline 0 & 33 & 19.53 \\
\hline 1 & 72 & 42.6 \\
\hline 2 & 37 & 21.89 \\
\hline 3 & 16 & 9.47 \\
\hline 4 & 9 & 5.33 \\
\hline 5 and above & 2 & 1.18 \\
\hline Residence & & \\
\hline Urban & 51 & 30.18 \\
\hline Rural & 118 & 69.82 \\
\hline
\end{tabular}

The clinical presentation is shown in Table $2.72 .79 \%$ patients presented at a gestational age of 7-12 weeks. The most common presenting symptom was abdominal pain in $61.64 \%$ patients followed by vaginal bleeding $(16.57 \%)$.

Table 2: Clinical features.

\begin{tabular}{|lll|}
\hline Presenting symptoms & $\begin{array}{l}\text { Number } \\
(\mathbf{n = 1 6 9 )})\end{array}$ & $\begin{array}{l}\text { Percentage } \\
(\%)\end{array}$ \\
\hline Amenorrhoea (weeks) & & \\
\hline$<6$ & 43 & 25.44 \\
\hline $7-12$ & 123 & 72.79 \\
\hline$>12$ & 3 & 1.78 \\
\hline Abdominal pain & 104 & 61.64 \\
\hline Vaginal bleeding & 28 & 16.57 \\
\hline Syncopal attack & 22 & 13.02 \\
\hline Shock & 13 & 7.69 \\
\hline Abdominal distension & 2 & 1.18 \\
\hline
\end{tabular}

Risk factors were found in $86(50.8 \%)$ patients. 38 $(44.1 \%)$ had history of previous tubal surgery (tubal sterilization and/or recanalisation) while 32 (37.2\%) patients had history of induced abortion as risk factor for ectopic gestation (Table 3). Other associated risk factors were history of infertility treatment $(3.48 \%)$, history of previous ectopic pregnancy $(8.13 \%)$ and pelvic inflammatory disease $(6.97 \%)$.

Table 3: Risk factors.

\begin{tabular}{|ll|l|}
\hline Risk factors & Number $(\mathbf{n = 8 6})$ & Percentage $(\%)$ \\
\hline Previous abortion & 32 & 37.2 \\
\hline Infertility treatment & 3 & 3.48 \\
\hline Tubal surgery & 38 & 44.1 \\
\hline Previous ectopic & 7 & 8.13 \\
\hline Pid & 6 & 6.97 \\
\hline
\end{tabular}


Table 4 shows that $131(89.1 \%)$ patients presented as ruptured ectopic gestation at the time of presentation. 147 patients underwent laparotomy, 131 were found have ruptured ectopic gestation, $9(6.1 \%)$ were in unruptured state and $7(4.7 \%)$ had tubal abortion. $114(77.5 \%)$ patients had gestation in the ampullary region of fallopian tube followed fimbrial region $(27,18.3 \%)$. Right sided ectopic pregnancies were more common as compared to the left side (Table 4).

Table 4: Intra-operative findings.

\begin{tabular}{|lll|}
\hline & Number $(\mathrm{n}=147)$ & Percentage (\%) \\
\hline Ruptured & 131 & 89.1 \\
\hline Unruptured & 9 & 6.1 \\
\hline Tubal abortion & 7 & 4.7 \\
\hline TO Mass & 12 & 8.1 \\
\hline Adhesions & 15 & 10.2 \\
\hline Site of ectopic & & \\
\hline Ampulla & 114 & 77.5 \\
\hline Fimbrial & 27 & 18.3 \\
\hline Isthmus & 5 & 3.4 \\
\hline Ovarian & 1 & 0.68 \\
\hline Side of ectopic & & \\
\hline Right & 94 & 63.9 \\
\hline Left & 53 & 36 \\
\hline Surgical procedure & & \\
\hline Salpingectomy & 140 & 95.2 \\
\hline Salpingostomy & 6 & 4.08 \\
\hline $\begin{array}{l}\text { Salpingo- } \\
\text { oopherectomy }\end{array}$ & 1 & 0.68 \\
\hline Quantity of hemoperitoneum $(\mathrm{ml})$ & \\
\hline$<500$ & 66 & 44.8 \\
\hline $500-1000$ & 47 & 31.9 \\
\hline $1000-1500$ & 14 & 9.5 \\
\hline $1500-2000$ & 9 & 6.1 \\
\hline $2000-2500$ & 7 & 4.7 \\
\hline $2500-3000$ & 4 & 2.7 \\
\hline & & \\
\hline
\end{tabular}

Out of 147 patients, $66(44.8 \%)$ patients had hemoperitoneum less than $500 \mathrm{ml}, 47$ (31.9\%) between $500-1000 \mathrm{ml}, 14(9.5 \%)$ patients had hemoperitoneum between $1000-1500 \mathrm{ml}$ and $20(13.6 \%)$ patients had hemoperitoneum more than 1.5 litres (Table 4).

Most common surgical procedure employed was salpingectomy in $140(95.2 \%)$ patients. Salpingostomy was done in $6(4.08 \%)$ patients and one patient underwent salpingo-oopherectomy (Table 4). 64 (43.5\%) patients required blood transfusion in intra-operative and postoperative period. Histopathological report confirmed ectopic gestation in all surgically treated patients. There was no maternal mortality from ectopic pregnancy in our case series.

\section{DISCUSSION}

Ectopic pregnancy is a life threatening condition especially when ruptured. The incidence of ectopic pregnancy in our centre was $1.6 \%$ which is comparable to similar studies by Olarewaju et al $(1.7 \%)$ in Jos and Gharoro and Igbafe in Benin, Nigeria. ${ }^{6,7}$ It is however higher than 1 in $161(0.6 \%)$ by Arup Kumar et al in India and 1 in $250(0.4 \%)$ of the ICMR multi-centre study, also in India. ${ }^{4,8}$

In our case series, the dominant age bracket was from 2024 years old $(50.89 \%)$. This age bracket was similar to Osaheni et al who found a dominant slice from 20 to 24 years old. ${ }^{9}$ This corresponds to the age of reproduction and peak sexual activity. The highest incidence of ectopic pregnancy was noted amongst nulliparous women $(19.53 \%)$ and pauciparous women (42.6\%). This observation is also made by almost all the authors who estimate that ectopic pregnancy is associated to low parity. $^{10,11}$

The exact aetiology of ectopic pregnancy is not known but different risk factors have been implicated as contributing element. In this study, $86(50.8 \%)$ out of 169 patients had risk factors. The most common risk factor in our study was found to be the history of tubal surgery $(44.1 \%)$ followed by history of previous abortion (37.2\%). Previous tubal surgery and previous ectopic pregnancy are the strongest risk factors associated with occurrence of ectopic pregnancy. ${ }^{12}$ The patients undergoing tubal sterilization and tubal recanalisation should always be counselled for early reporting in case of amenorrhoea, lower abdominal pain and irregular vaginal bleeding.

Lower abdominal pain was the commonest clinical presentation in our subjects. The symptoms at presentation: lower abdominal pain, amenorrhoea, syncopal attack and vaginal bleeding followed the global trend. ${ }^{4,7}$

The maximum number of patients of ectopic gestation were ruptured between 7 and 12 weeks $(72.79 \%)$ in our case series and the approximate results had been observed by Meye J.F. et al and Odefinmi F et al. ${ }^{10,13}$ This can be explained by the fact that as the egg gets bigger and at this gestational age, the villosity development will cause tubal erosion and rupture.

Regrettably, $131(89.1 \%)$ of the patients had ruptured ectopic pregnancy. This is similar to findings from developing countries where 70 to $95 \%$ of cases are ruptured at the time of presentation. ${ }^{5,14}$ Most of the patients had ampullary (77.5\%) ectopic pregnancy which had also been as the commonest site by other studies. The preponderance of ectopic pregnancies on the right is similar to the trend all over the world. ${ }^{5,15-17}$

Although, surgery is the mainstay of management, expectant and medical therapy can be offered to prevent fertility impairment. ${ }^{4}$ However, in our study, salpingectomy was done in majority $(95.2 \%)$ of patients due to late presentation. in most of the developing 
countries, as the patient present late with massive hemoperitoneum, surgical management remains the mainstay of management. ${ }^{18}$ The management option in our study was in line with recommendations of the National institute of clinical excellence that women with such presentation of ectopic pregnancy should have a salpingectomy. ${ }^{19}$

In our case series, we had no maternal mortality, similar to Makurdi study. ${ }^{20}$ Other studies had mortality rates of 1.5 to $3.7 \% .^{14,20-22}$ No significant morbidity was encountered in our series.

\section{CONCLUSION}

Ectopic pregnancy still remains a major life threatening emergency, associated with appreciable morbidity and mortality. Efforts to prevent deaths related to ectopic pregnancy must ensure early access to care, promote awareness about risk factors and early pregnancy testing. Women with history of previous tubal surgery, previous abortion and previous ectopic pregnancy should be followed up carefully, even in the absence of symptoms and should always be counselled about the possibility of ectopic pregnancy and the associated risks. Emphasis should be on prevention and early detection so as to give patients opportunities for tubal conserving management.

Funding: No funding sources

Conflict of interest: None declared

Ethical approval: Not required

\section{REFERENCES}

1. Sara HG, Uzelac PS. Early pregnancy risks. In: DeCherney AH, Nathan L, Goodwin MT, Laufer N, editors. Current Diagnosis and Treatment: Obstetrics and Gynecology. 10 ${ }^{\text {th }}$ ed. Columbus $(\mathrm{OH})$ : McGrawHill; 2007:259-272.

2. Panti A, Ikechukwu NE, Lukman OO, Yakubu A, Egondu SC, Tanko BA. Ectopic pregnancy at Usmanu Danfodiyo University Teaching Hospital Sokoto: a ten year review. Ann Niger Med. 2012;6(2):87-91.

3. Abdul FI. Ectopic pregnancy in Illorin: a review of 278 cases. Niger J Med. 2000;9(3):92-6.

4. Arup KM, Niloptal R, Kakali SK, Pradip KB. Ectopic pregnancy- an analysis of 180 cases. Journal of the Indian Med Assoc. 2007;105:308-14.

5. Gharoro EP, Igbafe AA. Ectopic pregnancy revisited in Benin City, Nigeria: analysis of 152 cases. Acta Obstet Gynecol Scand. 2002:81(12):1139-43.

6. Walker JJ. Ectopic pregnancy. In: clinical obstetrics and gynaecology. Lippincott William and Wilkins, Inc. 2007;50(1):89-99.
7. Olarewaju IAO, Ujah JA, Otubu M. Trends of ectopic pregnancy at Jos University Teaching Hospital Jos Nigeria. Niger Med J. 1994;2(26):5760.

8. ICMR: ICMR Task Force Project: multicenter case control study of ectopic pregnancy in India. J Obstet Gynaecol India. 1990:40:425-30.

9. Lawani OL, Anozie OB, Ezeonu PO. Ectopic pregnancy: a life-threatening gynecological emergency. International Journal of Women's Health. 2013;5:515-21.

10. Meye JF, Sima-Zue A, Ole BS, Kendjo E, Engongah-Beka T. Current aspects of extra-uterine pregnancy in Libreville (Gabon): an account of 153 cases. Sante. 2002;12:405-8.

11. Janecek J. Extra-uterine pregnancy. In: vokaer R. Treaty of obstetric, $1^{\text {st }}$ edn MASSON; 1995:83-100.

12. Ankum WM, Mol BW, Veen F, Bossuyt PM. Risk factors for ectopic pregnancy: a meta-analysis. Fertil Steril. 1996;65:1093-9.

13. Odejinmi F, Rizzuto MI, Macrae R, Olowu O, Hussain M. Diagnosis and laparoscopic management of 12 consecutive cases of ovarian pregnancy and review of literature. J Minim Invasive Gynecol. 2009;16:354-59.

14. Igbarese GO, Ebeigbe PN, Igbekoyi OF, Ajufoh BI. Ectopic pregnancy an 11 year review in a tertiary centre in the Niger Delta. Trop Doct. 2005;35:175-7.

15. Sotubo O, Aboyeji AP. Ectopic pregnancy in Ilorin, Nigeria: a five-year review. Niger Med Pract. 1994;27(3):25-7.

16. Practice committee of the American Society of Reproductive Medicine. Medical treatment of ectopic pregnancy. Fertil Steril. 2008;90(5):206-12.

17. Musa J, Daru PH, Mutihir JT, Ujah IA. Ectopic pregnancy in Jos Northern Nigeria-prevalence and impact on subsequent fertility. Niger $\mathrm{J}$ Med. 2009;18(1):35-8.

18. Swende TZ, Jogo AA. Ruptured tubal pregnancy in Makurdi, North Central Nigeria. Niger J Med. 2008;17(1):75-7.

19. National institute for health and care excellence. Ectopic pregnancy and miscarriage. 2012. Available at http://guidance.nice.org.uk/cg 154. Accessed 17 July 2013.

20. Ikeme AC, Ezegwui HU. Morbidity and mortality following tubal ectopic pregnancy in Enugu Nigeria. J Obstet Gynaecol. 2005;25(6):596-8.

21. Anorlu RI, Oluwole A, Abudu OO, Adebajo S. Risk factors for ectopic pregnancy in Lagos Nigeria. Acta Obstet Gynecol Scand. 2005;84(2):184-8.

22. Amoko DH, Buga GA. Clinical presentation of ectopic pregnancy in Transkei South Africa. East Afri Med J. 1995;72(12):770-3.

Cite this article as: Bhuria V, Nanda S, Chauhan M, Malhotra V. A retrospective analysis of ectopic pregnancy at a tertiary care centre: one year study. Int J Reprod Contracept Obstet Gynecol 2016;5:2224-7. 